\title{
THE INFLUENCES OF ENTREPRENEUR BEHAVIOR AND GROUP PARTICIPATION AGAINST BUSINESS PERFORMANCE THROUGH MOTIVATION
}

\author{
Danny Hendra Irawan \\ Hamidah Nayati Utami \\ Yusri Abdillah \\ Department of Business Administrative Science, Faculty of Administrative Science of Malang \\ Brawijaya University \\ Email: dannyirawan16@gmail.com
}

\begin{abstract}
ABSTRAK
Perkembangan UKM menjadi salah satu hal yang penting dalam perekonomian di Indonesia. Salah satu UKM yang saat ini terus berkembang adalah UKM di bidang pariwisata. UKM di bidang pariwisata merupakan bentuk kemandirian ekonomi masyarakat, seperti UKM kerajinan batik khas Blitar yang merupakan produk pariwisata. Dalam penelitian ini, menjelaskan tentang pengaruh entrepreneur behavior dan group participation terhadap kinerja usaha yang di mediatori oleh variabel motivasi. Jenis penelitian ini adalah explanatory research, dengan menggunakan kuesioner alat pengumpul data primer yang disebarkan kepada pemilik UKM batik khas Blitar. Sampel dalam penelitian ini adalah sampel jenuh, dengan menjadikan seluruh pemilik UKM batik khas Blitar menjadi sampel penelitian dengan jumlah sebanyak 77 responden. Analisis jalur dengan menggunakan SPSS 20,0 dipilih untuk menganalisis pengaruh variabel dalam penelitian ini. Hasil penelitian menunjukan bahwa entrepreneur behavior dan group participation berpengaruh positif dan signifikan terhadap motivasi dan terhadap kinerja usaha.
\end{abstract}

Kata Kunci: entrepreneur behavior, group participation, motivasi, kinerja usaha.

\begin{abstract}
Small Medium EnterpriseS (SME) development is one of essentials matters in Indonesia's economy. One of SME s which currently keeps growing is SME in tourism sector. SME in this sector is the form of people's economic independence, for example batik craft SME from Blitar which is a tourism product. This research explains about the influence of entrepreneur behavior and group participation against business performance managed by the variable of motivation. This type of research is an explanatory research using questionnaire as a primary data collection tool distributed to the owners of Blitar batik SME s. The sample of this research is saturated sample by making all Blitar batik SME owners as research samples up to 77 respondents. Path analysis using SPSS 20.0 is selected to analyze the influence of the variable in this research. The result of this research shows that entrepreneur behavior and group participation bring positive and significant influences against motivation and business performance.
\end{abstract}

Keywords: entrepreneur behavior, group participation, motivation, business performance. 


\section{INTRODUCTION}

The improvement of people's prosperity through tourism can be entrepreneurship in form of small and medium enterprises (SME), as conducted by people to lower unemployment rate by creating employment opportunities. People get motivation from the government through various measures to escalate the number of entrepreneurs in Indonesia which ideally reaches $2 \%$ of a country's population, as stated by Halim Alamsyah, Bank Indonesia Deputy Governor. The government provides supports by organizing training programs for free to people. The provision of soft loans to SME -scale entrepreneurs is expected to overcome a capital issue which often becomes a major issue.

There are several kinds of business which support tourism activities, including SME in batik industry. Batik industry in Indonesia is growing and draws attention from people and regional governments. After UNESCO assigned batik as the cultural heritage of Indonesia in 2009, its users increase in various social elements so the demand for batik cloth keeps increasing.

This research discusses Blitar batik SME as one of featuring tourism products in Blitar City and Blitar Regency. Creative industry in Blitar is interesting to be researched since it is the combination of batik creative industry and creative tourism. Creative tourism will be related to culture and cultural attraction which become the characteristics of a region and tourism attractions (Kostopoulou, 2013 in Damayanti \& Latifah, 2015). SME in batik industry may be a measure to enhance revenue and distribute opportunities to open business. It means people in local level have opportunities to improve their prosperity economically through tourism sector. In line with the research conducted by Latifah dan Damayanti (2016) stating that the impact of batik industry-based creative tourism against local economic development in Pekalongan City is the hike of batik entrepreneur's revenue which contributes to people's prosperity. It certainly becomes a challenge for local batik entrepreneurs to prepare strategies to keep competing by knowing and implementing good methods of entrepreneurship and motivational improvement to every batik artisan.

Regional governments encourage batik artisans to participate in various SME -related educational and training programs so they are expected to create products with competitive advantages. Moreover, promotions are conducted to attract tourists which impact the sales of batik from Blitar. Through exhibition activities either in local or national levels facilitated by regional governments and websites of tourism departments, the creation of featuring products' leaflets are expected to be facilities to market this creative tourism products. The development of SME has to be balanced with skill and knowledge about entrepreneurship by SME business players. Entrepreneur behavior will reflect how an entrepreneur sees opportunities and is able to control their business. Behavior is related to the attitude as an entrepreneur such as dare to make decisions, leadership, management capability, and everything related to scope of business (Suryana, 2011). Entrepreneur behavior is an essential component in running a business. It influences the performance of an entrepreneur by knowing everything to be conducted by entrepreneurs. The knowledge about entrepreneur behavior will allow an entrepreneur to appropriately determine their steps and to run their businesses. Entrepreneur must be tenacious, hard to give up, optimistic, and has high confidence, strong commitment, and courage in taking risks. Entrepreneur behavior will influence several business aspects, one of them is motivation. As explained before, one of entrepreneur behavior components is motivation. Motivation either from inside or outside of an entrepreneur can impact the success in running business, so entrepreneur behavior can contribute to business performance.

The existing association of Blitar batik artisans is a platform to interact and exchange knowledge. Cooperation and participation from every owner for the advance of business play important roles in the advance of batik business. Participation and awareness from association members to build Blitar batik industry will generate innovations and creativity in developing Bliar batik industry. Participation can start from the stages of planning and performance, management, supervising, to evaluation. The participation of the members of this batik artisan association is very influential for batik industry. If a batik artisan joining this association has active attitude, they will be able to build and develop batik industry properly. Moreover, the development of batik industry by 
involving member participation, for example in making decisions, will grow sense of dependence, sense of belongingness, and responsibility. Roberts et al., (2006) explains that participation has an important role against motivation so active participation from association members will enhance the motivation of group members. Wazir et al., (1999) states group participation is form of conscious and voluntary participation in social interaction.

The development of Blitar batik industry cannot be separated from the participation of this batik artisan group which joined a group having similar purposes. Strong participation is necessary so batik industrial management is expected to be well-managed and sustainable. Blitar located in the southern part of East Java has various traditions in its areas, adding the diversity of the existing batik patterns.

Besides group participation from Blitar batik artisan association members, motivation becomes one of the things to influence the performance of stakeholders. According to Azwar (2000), motivation is the form of stimulus, encouragement or energy booster which lies inside an individual or a group of people who work optimally together in conducting a business which has been planned to achieve the determined goals. Analysis of working achievement is always related to two major factors namely (1) willingness or motivation to work which generates business and (2) capability to conduct works, so working achievements are the functions of motivation and capability, formulated as $\mathrm{P}=\mathrm{f}(\mathrm{M} \times \mathrm{A} \times \mathrm{O})$, where $\mathrm{P}$ is performance, $\mathrm{M}$ is motivation, $\mathrm{A}$ is ability and $\mathrm{O}$ is Opportunity (Gomes, 1999). The formula clearly states that performance is influenced by motivation. The expert's explanation clearly specifies that motivation lies in every owner of Blitar batik artisans so the goals will be optimal and achieved.

The success form development and management of Blitar batik industry SME can be seen from its business performance. Performance refers to the overview of results which have been achieved from a series of activities in a certain period (Samsul, 2012). Performance, according to (Boso et al., 2013), is a result or the progress or an achievement or a result which has been achieved either in terms of finance or non-finance. Business performance is the result of how batik industrial business management which, in this research, is Blitar batik artisan's business managed to give contribution to the prosperity of these batik artisans. Business performance of Blitar batik artisans is the reflection of an entrepreneur behavior and participation in its management and development. It explains that motivation is one of the things influencing the business performance of an SME. With good performance, the potentials owned against Blitar batik industry can be well-absorbed, which will bring benefits for many parties, especially Blitar batik artisans including economic independence or natural preservation and people's culture.

Related to the background's described, the problems of this research are as follows:

1. Does entrepreneur behavior significantly influence motivation?

2. Does group participation significantly influence motivation?

3. Does entrepreneur behavior significantly influence business performance?

4. Does group participation significantly influence business performance?

5. Does motivation significantly influence business performance?

\section{THEORETICAL FRAMEWORKS \\ 2.1 Entrepreneur Behavior}

An entrepreneur has a commitment to work so they can obtain the results they expected. Tenacious, diligent, and hard to give up natures are the bases in conducting their works. Their actions are not based on speculations but through proper considerations. An entrepreneur dares to take risks since they have been through the proper considerations. Courage supported by robust commitments in an entrepreneur will encourage them to keep seeking opportunities to gain results (Suryana, 2011).

An entrepreneur behavior, as explained by Dani (2012), really influences the success of business performance. The first entrepreneur behavior is self-confidence owned by an entrepreneur. The second characteristic is task-oriented. The third one is risk taker in form of time, money, health, and life. The fourth behavior is leadership. Fifth, the characteristic of an entrepreneur is to have leadership and the sixth is future-oriented. 
According to Bird (1989), there are several entrepreneur activities reflecting an entrepreneur behavior namely to determine business to be conducted, analyze its strength and weakness, create products in form of commodity or service, observe market behavior, predict potential market, select appropriate and strategic locations for business, prepare for financial plan, prepare for production plan, prepare for management plan, and decide capital, for example borrowing capital to start business.

\subsection{Group Participation}

According to Ach. Wazir Ws et al., (1999), group participation can be defined as the participation of an individual consciously and voluntarily in a social interaction (group) in a specific or certain situation and condition. In other words, an individual can participate if they suitability to interact with or in a group through various processes of sharing with others in terms of value, tradition, feeling, loyalty, compliance, and mutual responsibility to the group. Meanwhile, according to Isbandi (2007), group participation is the involvement of an individual or people in identifying issues which occur in a group, then selecting their methods of settlement and making decisions as an alternative solution to solve the issues, and the involvement of people in evaluating the activities which have been conducted.

Mustapha dkk., (2013) explain that local people's participation is essential for the success of tourism industry in regions. Seen as a tourism product, local people's participation is deemed as one of tourism products since participation becomes a method to determine decisions and the form of local wisdom owned by the people. Cohen and Uphoff in Dwiningrum (2011) distinguish participation into four types namely:

1) Participation in decision-making process.

2) Participation in performance.

3) Participation in taking benefits.

4) Participation in evaluation.

\subsection{Motivation}

Sardiman (2007) states that motive can be defined as an encouragement within an individual to do something they wish to achieve. Motive can be said as an encouragement from inside and within a subject or an individual to do various forms of certain activities to achieve an objective they have determined. Motives can be regarded as an intern condition of an individual.

According to Azwar (2000), motivation is a form of encouragement or stimulus, which is an energy booster owned by an individual or a group which cooperates optimally to run, perform, and achieve an objective which has been planned or determined. Meanwhile, Swasto (2011) explains that motivation is a psychological condition which can provide encouragement from within an individual to meet needs and achieve objectives. According to the experts' opinions, motivation can be concluded as a psychological condition within an individual which is an encouragement to meet needs and desires, such as achieving objectives, self-satisfaction, selfactualization, social reason, and livelihood fulfillment.

According to Maslow's Need Hierarchy Theory, in Siagian (2004), human needs are constructed based on the hierarchy of importance, covering:

1. Physiological needs, which are the basic needs used to survive such as water, food, drink, house, having sex, and many more.

2. Safety needs, which are the needs against security, accident, and safety when working.

3. Social needs, which are the needs in social nature including socializing, making friends, being loved, and loving in public perspectives.

4. Esteem needs, which are the needs of self-acknowledgement and appreciation within working environment and society.

5. Self-actualization needs, which are the needs of an individual's selfactualization using skill, ability, capability, and self-potentials owned by an individual to achieve excellent and satisfying working achievements 
which are hardly achieved by others and to obtain appreciation from others.

\subsection{Business Performance}

Business performance is an essential thing since with good business performance, business' sustainability will be guaranteed. Performance refers to the level of achievement within certain periods. Business performance can be made as an indicator about the success or failure of a business. Moreover, business performance is the overview of results which have been achieved by a company from the series of working function performances or activities in a certain period (Bernadin and Russel in Samsir, 2012). From SME segment, Sugiarto (2006) explains that the success of performance is divided into points namely:

1. Business success indicators:
a. sales volume hike occurs.
b. additional value of a product increases.
c. the number of involved manpower increases.
d. business diversification.
e. market coverage gets wider.
f. investment hike.

2. Related entrepreneur's performance indicators:
a. achievement motivation point increases.
b. managerial capability improves.
c. more innovative and creative in managing business.
d. good human relation minded.

Due to the limitation of small industrial business, including tourism industry in tourism villages in conducting recording, then measuring business performance using the perceptions of owners or managers by implementing performance measures from the research conducted by Lee and Tsang (2011) shows that in measuring business performance variables, the following indicators are used:
1. sales volume hike
2. business asset hike
3. business profitability.

III. CONCEPTUAL FRAMEWORKS AND HYPOTHESIS

\subsection{Conceptual Frameworks}

Concept is a term and definition used to abstractly describe an event, situation, group, or individual which becomes a center of attention in social science (Singarimbun, 2006). This research discusses entrepreneur behavior in form of the SME of Blitar batik industry and the influence of group participation through motivation against business performance. The development of tourism sector is expected to improve people's prosperity through Blitar batik industry which is one of tourism products. In this research, there are four concepts to be studied namely entrepreneur concept, group participation concept, motivational concept, and business performance concept. According to the previous explanation, the concept models in this research are as follows:

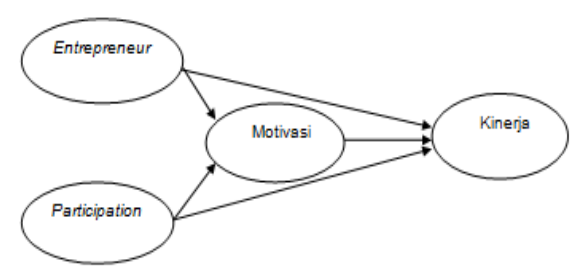

\section{Image 1. Concept Models}

Information:

$\longrightarrow$ : relationship between entrepreneur behavior, group participation, and motivation against business performance.

\subsection{Hypothesis Model}

Hypothesis is a method of solution or a temporary answer from the problems of a research, in a problem whose purpose is to guide researchers to seek answers before proving the truth through a theory (Sugiyono, 2005). Hypothesis model can be described as follows:

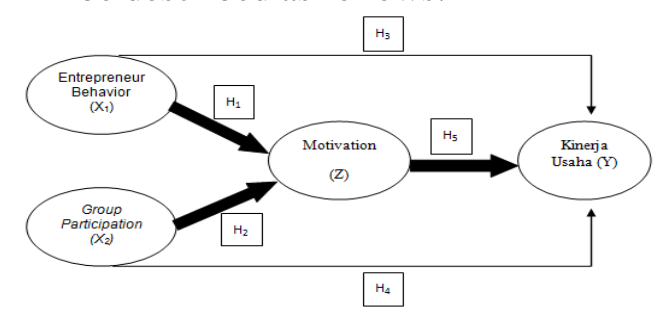

Image 2. Hypothesis Model 
Information:

$\longrightarrow$ : the influence of $X_{1}, X_{2}$ variables partially against $Y$ variable.

$\longrightarrow$ : the influence of $X_{1}, X_{2}$ variables against $\mathrm{Y}$ variable through $\mathrm{Z}$ variable.

According to the reference of concept model development continued to a hypothesis model, the hypothesis of this research can be specified as follows:

H1: Entrepreneur behavior significantly influences motivation.

$\mathrm{H} 2$ : Group participation significantly influences motivation.

H3: Entrepreneur behavior significantly influences business performance.

H4: Group participation significantly influences business performance.

H5: Motivation significantly influences business performance.

\section{METHOD OF RESEARCH}

The type of research for this research is an explanatory research with a quantitative approach. This research aims to explain how great the influence of entrepreneur behavior and group participation against business performance through motivation, based on existing facts through hypothesis tests. This research is conducted on the SME of Blitar batik industry in Blitar. Blitar is one of batik artisan regions in East Java Province.

The populations in this research are 77 Blitar batik SME s in Blitar City and Regency. For samples, the researcher use all population or known as saturated sample or census, by involving 77 Blitar batik SME owners joining Blitar batik artisan associations. Census or saturated sample method is used when a research population is less than 100 or the number of respondents is relatively small and the data collection can be easily conducted (Arikunto, 2010). The data is collected by taking primary data through questionnaires distributed to respondents. The scale of measurement in this research uses Likert scale.

Validity test is conducted by comparing the result of correlation of coefficient between item and total modifier compared to its critical value. If its correlation of coefficients is found higher than its critical value, it is valid. Whether an item is deemed valid can be known by comparing the correlation index of a product moment ( $\mathrm{r}$ calculation) with its critical value or probability.

The formula to calculate $\mathrm{r}$ is as follows (Arikunto, 2006). Validity test with test technique uses the correlation technique of Pearson's Product Moment and uses the rate of significance of $5 \%$, to know the closeness of influence between exogenous and endogenous variables and the following Product Moment Coefficient of Correlation formula is used:

$$
r=\frac{n\left(\sum X Y\right)-\left(\sum X \sum Y\right)}{\sqrt{\left[n \sum X^{2}-\left(\sum X\right)^{2}\right]\left[n \sum Y^{2}-\left(\sum Y\right)^{2}\right]}}
$$

Information:

$\mathrm{r}=$ correlation of product moment

$\mathrm{i}=$ grain score

$\mathrm{X}=$ exogenous variable

$\mathrm{Y}=$ endogenous variable

$\mathrm{n}$ = amount of sample

This reliability test is conducted by testing the scores among items to test their reliability rates. In this research, Alpha cronbach (Arikunto, 2006) method is used:

Information:

$$
r_{11}=\left[\frac{k}{k-1}\right]\left[\frac{\sum \sigma^{2} b}{\sigma^{2} 1}\right]
$$

$\mathrm{r}_{11}=$ reliability of instrument

$\mathrm{k} \quad=$ amount of question

$\sum \sigma^{2} b=$ grain variant score

$\sigma^{2}{ }_{1}=$ total variant

Reliability test in this research is assisted by SPSS version 20.0 program. The result of reliability test can be known if the value of Alpha Cronbach obtained for the variables of Entrepreneur Behavior $\left(\mathrm{X}_{1}\right)$, Group participation $\left(\mathrm{X}_{2}\right)$, Business performance $(\mathrm{Y})$, and Motivation $(\mathrm{Z})$ are more than the standard value of 0.6. The Alpha values of each variable are suitable with the terms stated previously so it can be concluded that the research instruments used to measure the four variables in this research are reliable and have high reliability.

\section{RESULT OF RESEARCH AND DISCUSSION}

\subsection{Influence of Entrepreneur Behavior against Motivation}

The result of descriptive statistical test from entrepreneur behavior variable shows that 13 items are proposed and generate the average value of 4.46 categorized as very good. Meanwhile, for motivation variable, 6 items are proposed and generate the average value of 4.46 categorized as very good. In path analysis, the 
result shows that the relationship of entrepreneur behavior generates beta coefficient value of 0.446 with $p$-value of 0.000 (p-value is less than 0.005). This result shows that the better the entrepreneur behavior owned by Blitar batik artisans, the higher the motivation they will have.

\subsection{Influence of Group Participation against Motivation}

The result of descriptive statistical test shows that group participation variable consisting of 4 items has the average value of 4.37 while motivation variable consisting of 6 items has the value of 4.46 . The value describes that group participation in the members or individuals of Blitar batik artisans is very good. The result of path analysis shows that beta coefficient of 0.378 which means the influence of Group participation against Motivation with $\mathrm{t}_{\text {hitung }}$ of 3.952 and probability of $0.000(\mathrm{p}<0.05)$, then the decision is that $\mathrm{H}_{0}$ is accepted, meaning that the hypothesis stating that Group participation positively and significantly influences Motivation is accepted. It shows that better Group participation will boost motivation to Blitar batik UKMs significantly. Determination coefficient value $\left(\mathrm{R}^{2}\right)$ is 0.526 or $5.26 \%$. The result shows that the contribution of Entrepreneur Behavior and Group Participation against Motivation reaches $52.6 \%$ while the contribution of other variables outside the model of this research reaches $47.4 \%$.

\subsection{Influence of Entrepreneur Behavior against Business Performance}

The result of descriptive statistical test shows that Entrepreneur behavior variable consisting of 13 items has the average value of 4.46 while business performance variable consisting of 6 items has the value of 4.39. The value describes that entrepreneur behavior in the members or individuals of Blitar batik artisans is very good. The path analysis result shows beta coefficient of 0.209 , meaning that the influence of Entrepreneur behavior against business performance has a positive direction, with $t_{\text {hitung }}$ of 2.056 and probability of 0.043 $(\mathrm{p}<0.05)$, then the decision is that $\mathrm{H}_{0}$ is rejected, meaning that the hypothesis stating that entrepreneur behavior has direct positive and significant influence against business performance is accepted. The positive relationship direction shows that if entrepreneur behavior is improves, it will be followed by business performance improvement in Blitar batik SME s. It shows that better entrepreneur behavior will significantly improve the performances of Blitar batik SME s.

\subsection{Influence of Group Participation against Business Performance}

The result of descriptive statistical test shows that group participation variable consisting of 4 items has the average value of 4.37 while business performance variable consisting of 6 items has the value of 4.39 . The value describes that group participation in the members or individuals of Blitar batik artisans is very good. Path analysis result shows beta coefficient of 0.438 , meaning that the influence of group participation against business performance has a positive direction, with $t_{\text {hitung }}$ of 4.451 and probability of $0.000(p<0.05)$, then the decision is $\mathrm{H}_{0}$ is refused, meaning that the hypothesis stating that group participation has direct positive and significant influence against business performance is accepted. The positive relationship direction shows that if group participation is improved, it will be followed by the improvement of business performance in Blitar batik SMEs. It shows that better group participation will significantly improve the performance of Blitar batik SMEs.

\subsection{Influence of Motivation against Business Performance}

The result of descriptive statistical test shows that motivation variable consisting of 6 items has the average value of 4.46 while business performance variable consisting of 6 items has the value of 4.39. The value describes that the motivation of Blitar batik artisans is very good. The result of path analysis shows beta coefficient of 0.243 , meaning that the influence of motivation against business performance has a positive direction, with $t_{\text {hitung }}$ of 2.238 and probability of $0.028(p<0.05)$, then the decision is that $\mathrm{H}_{0}$ is refused, meaning that the hypothesis stating that motivation significantly and positively influences business performance is accepted. The positive relationship direction shows that if motivation is improved, it will be followed by the improvement of business performance in Blitar batik SME s. It shows that better motivational level will significantly improve the performance of Blitar batik SME s. 


\subsection{Relationship among Paths}

The model of path analysis is as follows:

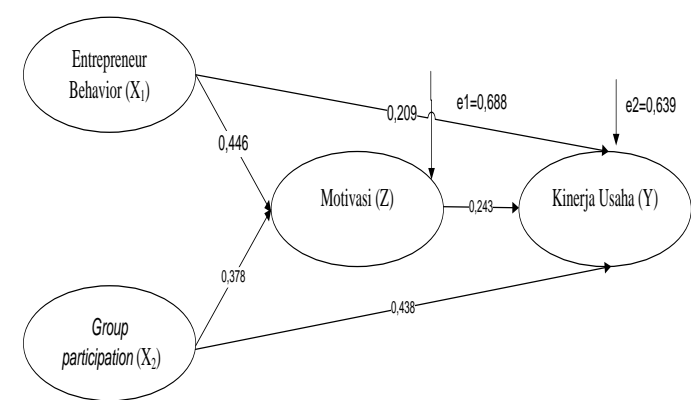

Image 3. Path Analysis

\section{CONCLUSION AND SUGGESTION 6.1 Conclusion}

According to the formulated problems, the result of analysis and hypothesis testing conducted in the previous chapter, the research can be concluded as follows:

1. The research shows that Entrepreneur behavior variable has positive and significant influence to Motivation (Z), meaning that significant influences exist. Entrepreneur behavior is one of essential components since it is the basis in conducting business activities which has to be owned and implemented by entrepreneurs to achieve good performances. The positive and significant influence between entrepreneur behavior and motivation variables becomes one of boosters to improve business performance. It impacts motivational improvement to run business better, improve achievement level, and maintain business sustainability.

2. Research shows that Group participation variable has positive and significant influence to Motivation ( $\mathrm{Z}$ ) proven by its probability value, meaning that significant influences on both variables exist. Group participation having positive and significant influences against motivation describes that the empowerment within batik artisan groups produces positive results to the performed business. The involvement of Blitar batik association members in every business activity including in organized activities has boosted sense of belongingness and strong bonds, generating sense of responsibility to maintain the management of Blitar batik business from within Blitar batik association members.

3. Research shows that Entrepreneur behavior variable has positive and significant influence against Business Performance (Y) proven by its probability value, meaning that significant influences exist. Better entrepreneur behavior in batik entrepreneurs will boost business performance. The development of a business can happen if business management capability can be well-applied. Better entrepreneur behavior owned by Blitar batik artisans balanced with appropriate strategies can bring contribution to business development or business performance improvement.

4. Research shows that Group participation variable has positive and significant influence to Business Performance (Y) proven by its probability value, meaning that significant influences exist. In this case, Group participation really influences and assists in establishing cooperation in a business group. Exchange of information and knowledge when joining Blitar batik artisan associations promotes better business management, such as quality improvement in production, update and creativity improvement, or related to product sales, so group participation also directly improves the business performance of Blitar batik artisan associations.

5. Research shows that Motivation variable has positive and significant influence to Business Performance (Y) proven by its probability value, meaning that significant influences exist. High motivation owned by every batik artisan improves their performances to meet their economic needs. Motivation can encourage an individual to work well and influences their performance qualities. The motivation within an individual to meet physiological and social needs encourages Blitar batik entrepreneurs to have excellent business performance to meet their business targets and generate expected income.

\subsection{Suggestion}

Based on the result of this research, several suggestions can be identified as follows:

1. Blitar batik SME players are expected to maintain and improve the qualities of Entrepreneur Behavior and Group Participation since those variables have significant influences to Business Performance or through Motivation, so Business Performance will be better. 
Meanwhile, path analysis shows that indirect influences from Group Participation against Business Performance through Motivation have the highest influential value of 0.530 . It shows that good Group Participation supported by high motivation can provide better business performance. Blitar batik SME players are expected to improve the level of participation in Blitar batik artisan associations, for example organizing regular meetings which can enhance knowledge about batik, improve production, improve human resource quality, enhance business capital and sales, and being involved in promotional activities including SME exhibitions organized by regional governments by forming committees and packing the activities as attractive as possible to enhance sales revenue.

2. Blitar batik SME players are expected to improve their management skills so the production of Blitar batik can be well-organized, including having good accounting reporting management.

3. Since the independent variables in this research are essential in influencing Business Performance, this research is expected to be used as a reference for next researchers to develop this research by considering other variables besides those stated in this research.

4. Next researches are expected to be conducted on SMEs of greater scale to better describe SMEs performance.

\section{REFERENCES}

Ach. Wazir Ws., et al., ed. (1999). Panduan Penguatan Menejemen Lembaga Swadaya Masyarakat. Jakarta: Sekretariat Bina Desa dengan dukungan AusAID melalui Indonesia HIV/AIDS and STD Prevention and Care Project.

Ajzen, I. (2005). Attitudes, Personality and Behavior. New York. USA: Open University Press.

Aladwani, Adel M;Rai, Arun; Arkalgud; Ramaprasad. Formal Participation and Performance of the System
Development Group: The Role of Group Heterogeneity and Group-Based Reward. Database for Advances in Information Systems; Fall 2000; 31, 4; ProQuest pg. 25.

Arikunto, Suharsini. 2010. Prosedur Penelitian (Suatu Pendekatan Praktek). Edisi Revisi Keenam, Cetakan Ketigabelas. Jakarta: PT Asdi Mahasatya.

Dani, Ibrahim et al. 2012. Business Strategy Role as Mediation of Management Capability and Orientation of Entrepreneurship on Business Performance (A Study on Micro and Small Scale Seaweed Business in Takalar District, South Sulawesi Province). Journal of Management Research.Vol 5. http://www.macrothink.org/journal/ind ex.php/jmr/article/view/2774

Dwiningrum, S. I. Astuti. (2009). Desentralisasi dan Partisispasi Masyarakat Dalam Pendidikan. Yogyakarta : FIP UNY.

Lee, D.Y and Tsang, E. W.K. 2001. The Effect of Entrepreneurial Personality, Background and Network Activities on Venture Growth, Journal of Management Studies 38 (4): 538-602.

Roberts, Jeffrey A;Il-Horn Hann;Slaughter, Sandra A. Understanding the Motivation, Participation, and Performance of Open Source Software Developes: A Longitudinal Study of the Apache Projects. Management Science; Jul 2006; 52, 7; ABI/INFORM Collection pg. 984 .

Samsir. 2012. Pengaruh Lingkungan Industri, Inovasi, dan Kebijakan Pemerintah terhadap Kinerja Usaha ( Studi pada Industri Kecil Tenun Songket Riau Di Provinsi Riau). Desertasi. Universitas Brawijaya.

Sardiman, A.M. 2007. Interkasi dan Motivasi Belajar Mengajar. Bandung: Rajawali Press.

Siagian, Sondang P. 2004. Kiat Meningkatkan Produktivitas Kerja. Jakarta: Rineke Cipta. 
Singarimbun, Masri dan Sofian Effendi. 2006. Metode Penelitian Survey. Edisi Revisi. Cetakan Kedelapanbelas. Jakarta:LP3ES.

Sugiyono. 2005. Metode Penelitian Administrasi. Edisi Ketigabelas. Cetakan Pertama. Bandung: CV Alfabeta.

Sugiyono. 2007. Metode Penelitian Bisnis. Bandung: Alfabeta.

Sugiyono. 2009. Metode Penelitian Bisnis. Bandung: Alfabeta.

Suryana. 2011. Kewirausahaan Pedoman Praktis: Kiat Usaha dan Proses Menuju Sukses. Edisi Ketiga. Jakarta: Salemba Empat.

Swasto, Bambang. 2011. Manajemen Sumber Daya Manusia. Malang:UB Press.

Tilaar, H. A. R. 2009. Kekuasaan dan Pendidikan; Manajemen Pendidikan Nasionaldalam Pusaran Kekuasaan. Jakarta: Rineka Cipta.

Yuyun, Wirasasmita. 1993. Kerja sama Perguruan Tinggi dengan Lembaga Perbankan dan Keuangan Lainnya dalam Menciptakan Wirausahawirausaha Baru. Hasil Seminar. Bandung: LM-UNPAD

Zimmerer, W. Thomas, Norman M. Scarborought. 1996. Entrpreneurship and The New Venture Formation. New Jersey: Prencite Hall International,Inc.

http://www.seputarukm.com/idealnya-jumlahwirausaha-2\%-dari-total-penduduk/ diakses pada 30 Juni 201614.46

http://www.republika.co.id/berita/ekonomi/kor porasi/16/02/19/o2so9x359-99-persen-usahadi-indonesia-itu-pelaku-umkm diakses pada 30 Juni 2016 pukul 15.35. 